\title{
PENGARUH PERBEDAAN KONSENTRASI EKSTRAK Sargassum sp. DAN LAMA PENYIMPANAN TERHADAP OKSIDASI LEMAK PADA FILLET IKAN PATIN (Pangasius sp.)
}

\author{
The Effect of Different Concentrations Extract Sargassum sp. and Storage \\ Time of Lipid Oxidation at Catfish (Pangasius sp.) \\ Fatin Hidayati, Y.S. Darmanto dan Romadhon \\ Program Studi Teknologi Hasil Perikanan \\ Fakultas Perikanan dan Ilmu Kelautan, Universitas Diponegoro \\ J1. Prof. Soedarto, SH, Tembalang, Semarang, Jawa Tengah - 50275, Telp/fax. +6224 747698 \\ Email: fatin_hidayati@yahoo.com
}

Diserahkan tanggal 24 Nopember 2016, Diterima tanggal 14 Desember 2016

\begin{abstract}
ABSTRAK
Ikan patin merupakan ikan air tawar yang mengandung lemak dan protein tinggi sehingga apabila dilakukan penyimpanan rentan terjadi oksidasi yang mengakibatkan ketengikan. Sargassum sp. dengan kandungan fenol dan flavonoid mampu menghambat terjadinya oksidasi pada fillet ikan patin. Penelitian ini bertujuan untuk mengetahui pengaruh perbedaan ekstrak Sargassum sp. dan lama penyimpanan dalam menghambat terjadinya oksidasi pada fillet ikan patin. Materi yang digunakan dalam penelitian ini adalah ekstrak Sargassum sp. dan fillet ikan patin. Metode penelitian yang digunakan adalah experimental laboratories dengan menggunakan Rancangan Acak Lengkap (RAL) faktorial dengan 2 faktor yaitu konsentrasi ekstrak Sargassum sp. (0\%, 1\%, 1,5\% dan 2\%) dan lama penyimpanan (hari ke-0, hari ke-2, hari ke-4, dan hari ke-6. Hasil penelitian menunjukkan bahwa perbedaan penambahan konsentrasi ekstrak Sargassum sp. dan lama penyimpanan memberikan pengaruh nyata terhadap nilai PV, nilai TBA, kadar lemak, kadar protein, kadar air serta organoleptik $(\mathrm{P}<0,05)$. Hasil penelitian tahap I didapatkan rendemen Sargassum sp. dengan pelarut etanol 96\% sebesar 1,39\%, kandungan fenol 1,813\%, flavonoid 0,278\% dan aktivitas antioksidan dengan Ic 50 sebesar 99,1659 ppm (kuat). Hasil penelitian tahap II didapatkan nilai PV berkisar antara 2,03-19,82 meq/kg, nilai TBA 0,63-6,72 mg.mal/kg. Konsentrasi $1,5 \%$ merupakan konsentrasi terbaik ekstrak Sargassum sp. dalam menghambat oksidasi lemak pada fillet ikan patin selama penyimpanan.
\end{abstract}

Kata kunci: Antioksidan, Ekstrak Sargassum sp., Lama Penyimpanan, Oksidasi lemak, Fillet Ikan patin

\begin{abstract}
Catfish is a freshwater fish that contain high fat and protein so that if its stored it will susceptible to oxidation process which leads to rancidity. Sargassum $s p$. with its phenolic and flavonoid content are able to inhibit the oxidation process in catfish fillet. This research was aimed to know the effects of different concentrations of Sargassum sp. extracts and storage time in inhibiting the oxidation process in catfish fillet. The materials used in this research were Sargassum sp. extracts and catfish fillet. This research was using experimental laboratories research method with factorial Completely Randomized Research Design (CRD) of 2 factors which were concentrations of Sargassum sp. extracts (0\%, 1\%, 1.5\%, and 2\%) and storage time (0 day, 2 days, 4 days, and 6 days). The results showed that the adding of different concentrations of Sargassum sp. extracts and storage time gave significant effect to the PV value, TBA value, fat content, protein content, moisture content, as well as organoleptic point $(P<0.05)$. The results obtained from stage I research were the yields of Sargassum sp. with ethanol $96 \%$ solvent was $1.39 \%$, phenol content was 1.813\%, flavonoid was $0.278 \%$, and antioxidant activity was $99.1659 \mathrm{ppm}$ (categorized as strong antioxidant). The results obtained from stage II research were the PV value were ranged from 2.03 to $19.82 \mathrm{meq} / \mathrm{kg}$, TBA value were ranged from 0.63 to $6.72 \mathrm{mg} . \mathrm{mal} / \mathrm{kg}$. The $1.5 \%$ concentration was the best concentration of Sargassum sp. extracts in inhibiting the lipid oxidation of catfish fillet during storage.
\end{abstract}

Keywords: Antioxidant, Sargassum sp. Extracts, Storage Time, Lipid Oxidation, Catfish Fillet

\section{PENDAHULUAN}

Produksi ikan patin (dari budidaya kolam, keramba dan jaring apung, serta sawah) pada tahun 2001 sebesar 11.118 ton, kemudian naik menjadi 32.375 ton pada tahun 2005, tetapi pada tahun 2006 turun menjadi 31.490 ton (Suryaningrum, 2008). Produksi patin Indonesia pada tahun 2008 sebesar 52.470 ton yang didominasi oleh patin Siam yang berdaging kuning, sementara patin yang berdaging putih produksinya masih terbatas. Permintaan pasar global semakin meningkat 
terutama disebabkan karena tingkat kesegarannya yang tinggi, warna daging yang putih dan kandungan lemaknya yang rendah (Suryaningrum et al., 2010).

Kandungan protein pada fillet patin cukup tinggi,yaitu berkisar antara 12,94-17,52\% (bb), sedangkan kandungan lemaknya berkisar antara $0,89-1,23 \%$ (bb). Kandungan lemak fillet patin cukup rendah bila dibanding produk ikan lainnya. Pada ikan patin kandungan lemak yang tinggi terutama berasal dari bagian perut (belly), yaitu 54,43\% (bk) (Suryaningrum et al., 2010). Kandungan lemak mengakibatkan daging ikan mudah mengalami proses oksidasi yang dapat menyebabkan bau tengik. Proses pembusukan ikan disebabkan oleh aktivitas enzim, mikroorganisme dan oksidasi dalam tubuh ikan itu sendiri, sehingga ikan segar harus segera ditangani dengan baik agar layak konsumsi.

Salah satu metode dalam penanganan untuk mencegah kerusakan oksidatif pada pangan adalah dengan penggunaan antioksidan. Kegunaan antioksidan yang lain yaitu memperpanjang umur simpan dengan cara melindungi pangan dari proses kemunduran kualitas yang disebabkan oleh oksidasi seperti ketengikan. Senyawa kimia penangkal atau antioksidan adalah komponen yang dapat menunda atau mencegah oksidasi lemak, asam nukleat, atau molekul-molekul lain dengan cara menghambat inisiasi atau propagasi reaksi oksidasi berantai. Hal tersebut juga diungkapkan oleh Winarsi (2007), bahwa senyawa antioksidan merupakan suatu inhibitor yang mampu menginaktivasi berkembangnya reaksi oksidasi dengan cara mencegah terbentuknya radikal atau dengan mengikat radikal bebas dan molekul yang sangat reaktif.

Potensi rumput laut yang melimpah di perairan Indonesia belum dimanfaatkan secara menyeluruh. Biasanya penduduk pantai memanfaatkan rumput laut untuk sayur, lalapan, acar, kue, puding dan manisan. Terutama Sargassum sp. dengan kelimpahannya yang banyak terdapat di perairan Indonesia belum dimanfaatkan secara baik

Apabila dilihat dari kandungannya, Sargassum sp. mempunyai banyak kandungan senyawa aktif diantaranya karetenoid, laminarin, alginat, fukoidan, manitol, dan phlorotanin. Selain itu kandungan fenol dan flavonoid yang terdapat dalam Sargassum sp. bisa dimanfaatkan sebagai antioksidan alami. Hal tersebut bisa lebih mengembangkan produksi rumput laut Indonesia disamping produksi tanaman herbal yang sekarang ini sudah banyak digunakan sebagai antioksidan. Hal tersebut sesuai pendapat Septiana dan Ari (2012), bahwa Sargassum sp. merupakan salah satu jenis rumput laut coklat yang banyak terdapat di perairan Indonesia. Salah satu kandungan bioaktifnya dapat berpotensi sebagai antioksidan seperti fukoidan dan komponen fenolik.

Antioksidan sintetis memiliki efektifitas yang tinggi namun kurang aman bagi kesehatan, sehingga pengunaannya diawasi secara ketat di berbagai negara. Adanya kemampuan antioksidan dalam menangkap radikal bebas, maka diperlukan sebuah penelitian terhadap kandungan antioksidan pada alga coklat Sargassum sp. khususnya pada kandungan senyawa aktifnya mengingat alga coklat jenis ini belum banyak dimanfaatkan oleh masyarakat. Oleh karena itu dengan penelitian pengaruh perbedaan konsentrasi ekstrak Sargassum sp. dan lama penyimpanan nantinya dapat diketahui kemampuannya dalam menghambat oksidasi lemak pada fillet ikan patin (Pangasius sp.).

\section{METODE PENELITIAN}

\section{Materi Penelitian}

Sampel yang digunakan dalam penelitian ini adalah Sargassum sp. yang diperoleh dari pantai Krakal di Gunung Kidul, Yogyakarta yang dalam penanganannya dengan cara dimasukkan dalam kantong plastik hitam kemudian disimpan dalam cool box untuk menjaga suhu dan agar tidak terkena cahaya matahari secara langsung. Fillet ikan patin yang digunakan dalam penelitian itu diperoleh dengan cara membeli ikan patin hidup kemudian di fillet di Superindo Yogyakarta. Alat yang digunakan dalam penelitian ini adalah rotary evaporator, timbangan analitik, vortex, Spektrofotometer UVVis, Soxhlet, Kjedahl, desikator, oven, $\mathrm{pH}$ meter.

\section{Metode Penelitian \\ Penelitian Tahap I}

Penelitian tahap I dengan melakukan pengeringan sampel Sargassum sp. kemudian ekstraksi sampel dengan menggunakan pelarut etanol $96 \%$ (polar). Ekstraksi yang dilakukan yaitu maserasi, dimana pada saat melakukan ekstraksi hanya melakukan perendaman pada sampel. Penelitian tahap I dilakukan dengan tujuan untuk ekstraksi Sargassum sp. dengan metode maserasi menggunakan pelarut etanol 96\% dan mengetahui kandungan metabolit sekunder (fenol dan flavonoid) serta aktivitas antioksidannya. Prosedur ekstraksi mengacu pada penelitian Husni et al. (2015) dengan modifikasi. Sargassum sp. kering sebanyak $100 \mathrm{~g}$ dipotong kecil-kecil dengan gunting dan dimasukkan ke dalam botol kaca. Simplisia dimaserasi dengan pelarut etanol 96\% (polar) sebanyak $400 \mathrm{ml}$ sampai seluruh simplisia terendam di dalam botol kaca yang telah ditutup menggunakan alumunium foil. Maserasi selama 2 × 24 jam pada suhu ruang, kemudian disaring dengan kertas saring untuk memisahkan filtrat dengan residu. Filtrat hasil maserasi selanjutnya dievaporasi dengan rotary evaporator pada suhu $40^{\circ} \mathrm{C}( \pm 1$ jam) hingga terbentuk ekstrak yang sudah tidak tercium bau pelarut. Ekstrak hasil evaporasi digunakan untuk penambahan ekstrak Sargassum sp. sebagai antioksidan pada fillet ikan patin. Setelah itu dilakukan uji fenol, uji flavonoid dan uji antioksidan metode DPPH.

\section{Penelitian Tahap II}

Penelitian tahap II dilakukan dengan penambahan senyawa bioaktif dari Sargassum sp dengan cara direndam. diharapkan dapat meminimalisir oksidasi dan bau tengik yang dihasilkan serta kerusakan yang terjadi pada fillet ikan patin. Penambahan ekstrak Sargassum sp. sebagai antioksidan dengan konsentrasi $0 \%, 1 \%, 1,5 \%$ dan $2 \%$ dengan lama penyimpanan selama 0 hari, 2 hari, 4 hari dan 6 hari dalam suhu $\pm 14^{\circ} \mathrm{C}$. Setelah dilakukan penyimpanan dan pengujian akan diketahui pengaruh penambahan ektsrak Sargassum sp. dalam menghambat oksidasi pada fillet ikan patin.

\section{Parameter Pengujian}

Pengujian untuk ekstrak Sargassum sp. meliputi uji aktivitas antioksidan Metode DPPH (Djapiala et al., 2013), uji kadar fenolik Metode Folin-Ciocalteu (Hardiana et al., 2012), uji total flavonoid (Rohaeti et al., 2011). Pengujian kimia fillet ikan Patin meliputi uji angka peroksida (PV) (Muresan et al., 2010), uji Thio Barbituric Acid (TBA) (Khotimah et al., 2013), pengujian $\mathrm{pH}$ (BSN, 2004), uji kadar air, kadar lemak dan

(ㄷ) Copyright by Saintek Perikanan (Indonesian Journal of Fisheries Science and Technology), ISSN : 1858-4748 
Pengaruh Perbedaan Konsentrasi Ekstrak Sargassum Sp. dan Lama Penyimpanan terhadap Oksidasi Lemak pada Fillet Ikan Patin

kadar protein dengan mengacu pada panduan pengujian (AOAC, 2005) serta pengujian organoleptik (BSN, 2006).

\section{Rancangan Percobaan}

Rancangan percobaan yang digunakan dalam penelitian ini adalah Rancangan Acak Lengkap (RAL) faktorial yang terdiri dari 2 macam faktor yaitu faktor pertama dengan konsentrasi $0 \%, 1 \%, 1,5 \%, 2 \%$. Sedangkan untuk faktor kedua menggunakan lama penyimpanan selama 0 hari, 2 hari, 4 hari dan 6 hari dengan ulangan sebanyak tiga kali. Pengujian normalitas dan homogenitas dilakukan terlebih dahulu sebelum analisa ANOVA, agar dapat diketahui sifat data sehingga dapat dilakukan sidik ragam atau tidak. Metode analisa yang digunakan adalah sidik ragam ANOVA dengan uji lanjut untuk menentukan nilai yang berpengaruh maupun yang tidak dengan Uji BNJ (Beda Nyata Jujur).

\section{HASIL DAN PEMBAHASAN}

\section{Karakterisitik Sargassum sp.}

Berikut ini merupakan hasil dari karakteristik ekstrak Sargassum sp. :

Tabel 1. Karakteristik Ekstrak Sargassum sp.

\begin{tabular}{lll}
\hline Uji & Jumlah & Satuan \\
\hline Rendemen & $1,39 \pm 0,27$ & $\%$ \\
Fenol & $1,813 \pm 0,003$ & $\%$ \\
Flavonoid & $0,278 \pm 0,002$ & $\%$ \\
Antioksidan & 99,166 & ppm
\end{tabular}

Hasil rendemen ekstrak Sargassum sp. yang diekstraksi menggunakan pelarut etanol $96 \%$ sebesar $1,39 \%$, hasil rendemen yang didapatkan lebih besar apabila dibandingkan dengan penelitian Khotimah et al., (2013) yang menyatakan bahwa hasil rendemen Sargassum fillipendula yang didapatkan untuk isolat kuning kehijauan yaitu sebesar $0.33 \%$ dan untuk isolat orange sebesar $0.46 \%$. Hal tersebut berkebalikan dengan hasil penelitian Husni et al., (2014) bahwa persentase rendemen yang dihasilkan dari ekstraksi makroalga dengan menggunakan pelarut etanol berkisar 2-3\%. Jumlah rendemen ekstrak yang dihasilkan dipengaruhi oleh beberapa faktor, yaitu ukuran simplisia, jenis pelarut, tingkat kepolaran pelarut dan lama maserasi. Menurut Pendit (2016), tingkat kepolaran pelarut yang digunakan mempengaruhi tingkat kelarutan suatu senyawa bahan yang diekstraksi ke dalam pelarut. Jenis dan tingkat kepolaran pelarut menentukan jenis dan jumlah senyawa yang dapat diekstrak dari bahan. Rendemen ekstrak akan cenderung meningkat dengan semakin meningkatnya rasio bahan : pelarut yang digunakan.

Hasil uji fenolik dan flavonoid total ekstak Sargassum sp. menunjukkan bahwa Sargassum sp. mengandung senyawa fenol dan flavonoid. Besarnya kandungan senyawa bioaktif pada ekstrak tersebut adalah $1,813 \%$ (fenol) dan $0,278 \%$ (flavonoid). Kandungan senyawa flavonoid yang lebih kecil dibandingkan dengan senyawa fenol, karena senyawa flavonoid merupakan bagian dari senyawa fenol. Hal tersebut sesuai dengan penelitian Redha (2010), bahwa berdasarkan hasil-hasil penelitian yang telah dilakukan, diyakini bahwa flavonoid sebagai salah satu kelompok senyawa fenol yang memiliki sifat antioksidatif serta berperan dalam mencegah kerusakan sel dan komponen selulernya oleh radikal bebas reaktif. Senyawa fenol dan flavonoid dapat berfungsi sebagai senyawa antioksidan. Hal tersebut sesuai pendapat Rafsanjani et al., (2015), senyawa fenolik atau polifenolik yang dapat berupa golongan flavonoid, turunan asam sianat, kumarin, tokoferol dan asam-asam polifungsional dapat berfungsi sebagai senyawa antioksidan. Komponen fenolik dapat menghambat oksidasi lipid dengan menyumbangkan atom hidrogen kepada radikal bebas (Septiana dan Ari, 2012).

Berdasarkan hasil uji aktivitas antioksidan ekstrak Sargassum sp. dengan metode DPPH diperoleh hasil $\mathrm{IC}_{50}$ sebesar 99,1659 ppm. Hasil tersebut menunjukkan bahwa aktivitas antioksidan ekstrak Sargassum sp. tergolong kuat. Menurut Samin et al. (2013), suatu senyawa dinyatakan sebagai antiradikal bebas sangat kuat apabila nilai $\mathrm{IC}_{50}<50$ ppm, kuat apabila nilai $\mathrm{IC}_{50}$ antara $50-100$ ppm, sedang apabila nilai $\mathrm{IC}_{50}$ berkisar antara $101-250 \mathrm{ppm}$, lemah apabila nilai $\mathrm{IC}_{50}$ berkisar antara 250-500 ppm dan tidak aktif apabila $\mathrm{IC}_{50}$ diatas 500 ppm. Handayani et al., (2004), juga menambahkan bahwa senyawa berikutnya yang berpotensi sebagai antioksidan adalah flavonoid yang merupakan senyawa polifenol mempunyai kemampuan untuk menyumbangkan atom hidrogen kepada senyawa radikal bebas, maka aktivitas antioksidan senyawa polifenol dapat dihasilkan pada reaksi netralisasi radikal bebas atau pada penghentian reaksi berantai yang terjadi. Hal tersebut diperkuat dalam Septiana dan Ari (2012) menyebutkan bahwa aktivitas perendaman radikal bebas DPPH dari alga coklat spesies Sargassum sp. lebih tinggi dari alga merah. Komponen fenol dapat menghambat oksidasi lipid dengan menyumbangkan atom hidrogen kepada radikal bebas.

\section{Analisa Uji Angka Peroksida (PV)}

Berdasarkan nilai angka peroksida (PV) pada Gambar 1, terlihat kenaikan nilai PV terjadi pada fillet ikan patin dengan perbedaan penambahan ekstrak Sargassum sp. selama penyimpanan. Kenaikan nilai PV disebabkan karena asam lemak tak jenuh pada daging ikan mengalami oksidasi sehingga terurai menjadi senyawa peroksida dan hidroperoksida. Ketaren (1986), menyatakan bahwa kenaikan angka peroksida terjadi karena adanya oksidasi yaitu terjadi kontak antara oksigen dengan lemak, dimana oksidasi dimulai dengan pembentukan peroksida dan hidroperoksida, kadar peroksida dalam lemak akan meningkat seiring pertambahan waktu.

Penurunan nilai PV yang terjadi pada fillet ikan patin tanpa penambahan ekstrak Sargassum sp. selama penyimpanan disebabkan karena hidroperoksida (senyawa oksidasi primer) yang terbentuk sudah semakin sedikit terdekomposisi menjadi senyawa malonalehid (produk oksidasi sekunder). Menurut pendapat Dewi et al., (2011), angka peroksida yang lebih rendah bukan berarti menunjukkan kondisi oksidasi masih berjalan pada tahap awal tetapi dimungkinkan produk hasil oksidasi lemak sudah terurai menjadi senyawa lain pada tingkat lanjut. Hal ini ditambahkan oleh Harikedua (2012), yang menyatakan bahwa penurunan signifikan nilai peroksida setelah mencapai nilai maksimum menunjukkan bahwa peroksida adalah komponen yang kurang stabil dan sangat rentan untuk mengalami perubahan lanjutan yang menghasilkan produk oksidasi sekunder, seperti aldehid, keton, hidrokarbon, dan polimer lainnya. Batas toleransi nilai peroksida tertinggi dalam daging ikan yaitu $10-20 \mathrm{meq} / \mathrm{kg}$ (Huss, 1995).

Nilai PV pada perlakuan dengan penambahan ekstrak Sargassum sp. sebesar $1 \%, 1,5 \%$ dan $2 \%$ menunjukkan nilai yang berbeda nyata dibandingkan dengan kontrol. Perlakuan perbedaan lama penyimpanan juga berbedanyata terhadap nilai

() Copyright by Saintek Perikanan (Indonesian Journal of Fisheries Science and Technology), ISSN : 1858-4748 
PV. Perlakuan penambahan ekstrak Sargassum sp. menunjukkan nilai PV lebih rendah dibandingkan dengan kontrol. Penambahan konsentrasi eksrak Sargassum sp. sebesar $1,5 \%$ menujukkan kenaikan nilai PV yang lebih stabil dibandingkan dengan penambahan kosentrasi sebesar $1 \%$ dan 2\%. Hal ini disebabkan karena ekstrak Sargassum sp memiliki senyawa bioaktif seperti fenol dan flavonoid yang berperan sebagai antioksidan yang dapat menghambat oksidasi lemak. Hal tersebut sesuai dengan pendapat Khamidinal et al., (2007), bahwa kerusakan minyak atau lemak yang disebabkan oleh reaksi oksidasi dapat dicegah dengan penambahan antioksidan.

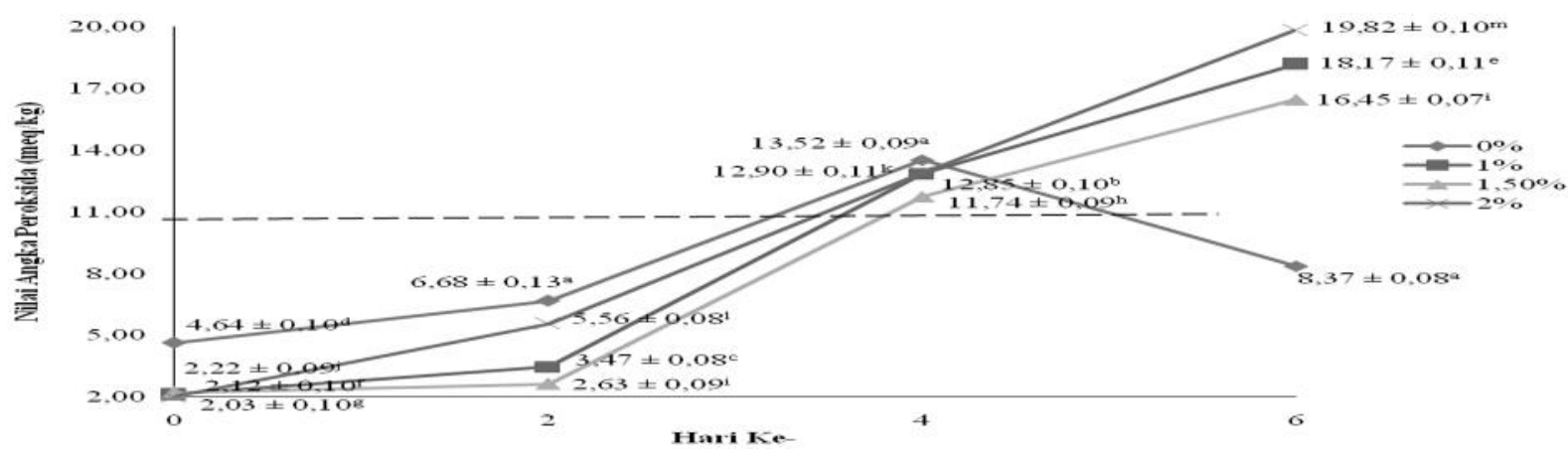

Gambar 1. Hasil Analisa Nilai Angka Peroksida (PV) pada sampel.

Keterangan: Data tersebut merupakan hasil rata-rata dari tiga ulangan \pm standar deviasi.

Data yang diikuti dengan tanda huruf kecil yang berbeda pada baris yang sama menunjukkan perbedaan yang nyata (P $0,05)$.

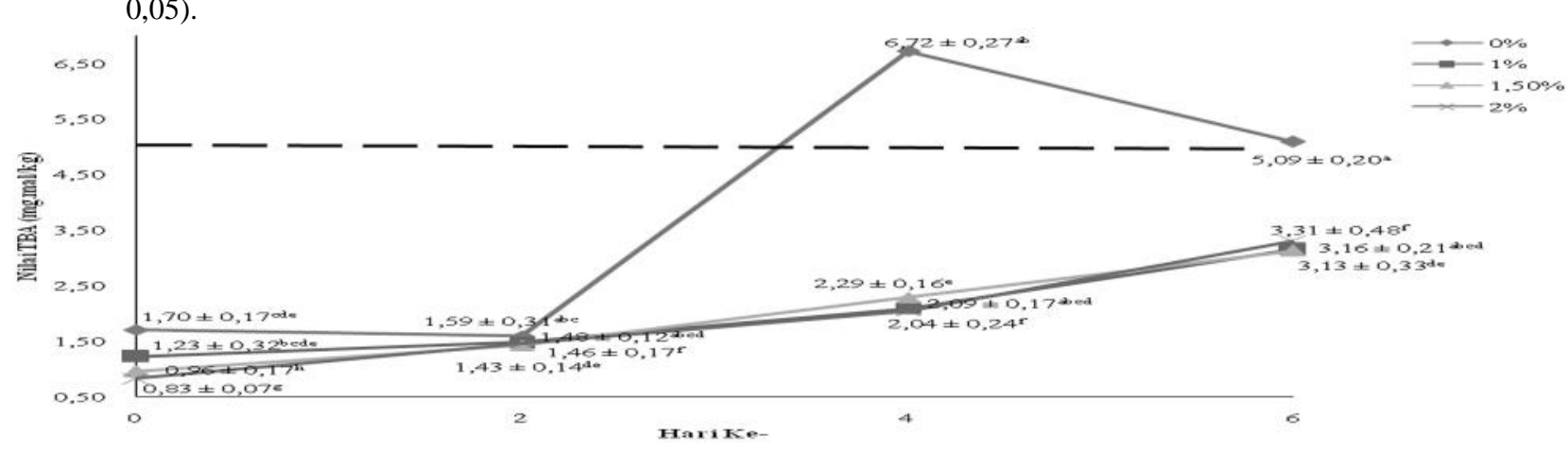

Gambar 2. Hasil Analisa Nilai TBA pada sampel.

Keterangan: Data tersebut merupakan hasil rata-rata dari tiga ulangan \pm standar deviasi.

Data yang diikuti dengan tanda huruf kecil yang berbeda pada baris yang sama menunjukkan perbedaan yang nyata (P $0,05)$.

Analisa Uji TBA (Thio Barbituric Acid)

Nilai TBA yang terdapat dalam Gambar 2, menunjukkan bahwa nilai TBA tanpa penambahan ekstrak Sargassum sp. mengalami kenaikan lalu mengalami penurunan, sedangkan dengan penambahan ekstrak Sargassum sp. mengalami kenaikan sedikit demi sedikit. Hal ini menunjukkan bahwa terdapat pengaruh antara fillet ikan yang ditambahkan ekstrak antioksidan Sargassum sp. dengan fillet ikan tanpa penambahan antioksidan. Menurut Prawira et al. (2015), bahwa pengukuran senyawa malonaldehida dalam suatu sistem dapat menjadi tolak ukur untuk aktivitas antioksidan. Senyawa antioksidan dapat menghambat pembentukan senyawa malonaldehida. Selain itu antioksidan dari ekstrak Sargassum sp. juga bisa digunakan untuk memperpanjang masa simpan fillet ikan. Hal ini sesuai dengan Harikedua (2012), bahwa antioksidan dapat memperpanjang umur simpan bahan pangan terhadap proses deteriorisasi yang disebabkan oleh oksidasi seperti ketengikan, perubahan warna dan hilangnya nilai nutrisi.
Nilai TBA pada perlakuan dengan penambahan ekstrak Sargassum sp. sebesar 1\%, 1,5\% dan 2\% menunjukkan nilai yang berbeda nyata apaila dibandingkan dengan setiap perlakuan terutama dengan kontrol. Perbedaan lama penyimpanan juga berbeda nyata terhadap nilai TBA. Perbedaan nilai TBA pada setiap konsentrasi tidak menunjukkan kenaikan yang signifikan, namun lebih menunjukkan kenaikan nilai TBA yang stabil. Apabila dibandingkan penambahan konsentrasi Sargassum sp. sebesar $1,5 \%$ mendapatkan kenaikan nilai TBA yang lebih stabil dibandingkan dengan penambahan konsentrasi sebesar $1 \%$ dan $2 \%$. Begitu juga apabila dibandingkan dengan kontrol, konsentrasi $1,5 \%$ mendapatkan nilai TBA yang jauh dibawah dengan kontrol (tanpa penambahan konsentrasi). Hal tersebut sesuai dengan pendapat Apriantono (2002), bahwa laju reaksi pembentukan dari dekomposisi hidroperoksida relatif lambat dibandingkan reaksi malonaldehid dengan asam amino, peptida dan senyawa lain. Perubahan angka TBA selama penyimpanan menunjukkan hasil yang fluktuatif. Hal ini diduga bahwa

(ㄷ) Copyright by Saintek Perikanan (Indonesian Journal of Fisheries Science and Technology), ISSN : 1858-4748 
malonaldehid bersifat sangat labil dan sangat reaktif terhadap protein dan asam amino karena malonaldehid merupakan hasil dekomposisi hidroperoksida. Batas toleransi ntuk nilai TBA tertinggi yang masih diterima dalam daging ikan yaitu $5 \mathrm{mg}$ eq/kg (Sallam, 2007).

\section{Analisa Uji pH}

Penentuan $\mathrm{pH}$ merupakan salah satu indikator pengukuran tingkat kesegaran ikan. Berdasarkan nilai $\mathrm{pH}$ yang terdapat pada Gambar 3, menunjukkan bahwa nilai $\mathrm{pH}$ fillet ikan patin tanpa penambahan ekstrak Sargassum sp. (kontrol) mempunyai $\mathrm{pH}$ yang lebih tinggi dibandingkan dengan perlakuan tambahan konsentrasi ekstrak Sargassum sp. Namun $\mathrm{pH}$ di semua perlakuan relatif asam atau rendah. Penyimpanan pada suhu dingin diduga berperan dalam menghambat kebusukan ikan dengan $\mathrm{pH}$ berkisar basa. Menurut Munandar et al., (2009), penggunaan suhu rendah mempengaruhi fluktuasi nilai $\mathrm{pH}$ pada ikan nila. Penyimpanan ikan nila pada suhu rendah menyebabkan aktivitas enzim yang terdapat pada daging menjadi terhambat sehingga kemunduran mutunya berjalan lebih lambat. Semakin rendah suhu yang digunakan maka aktivitas enzim semakin terhambat.

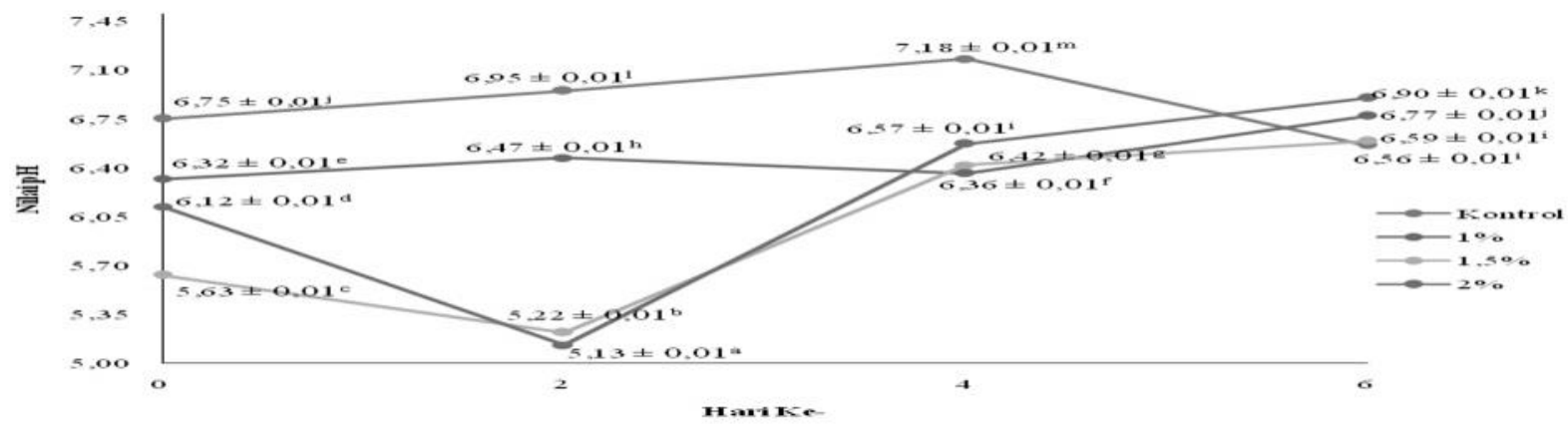

Gambar 3. Hasil Analisa Nilai pH pada sampel.

Keterangan: Data tersebut merupakan hasil rata-rata dari tiga ulangan \pm standar deviasi.

Data yang diikuti dengan tanda huruf kecil yang berbeda pada baris yang sama menunjukkan perbedaan yang nyata ( $P$ $0,05)$.

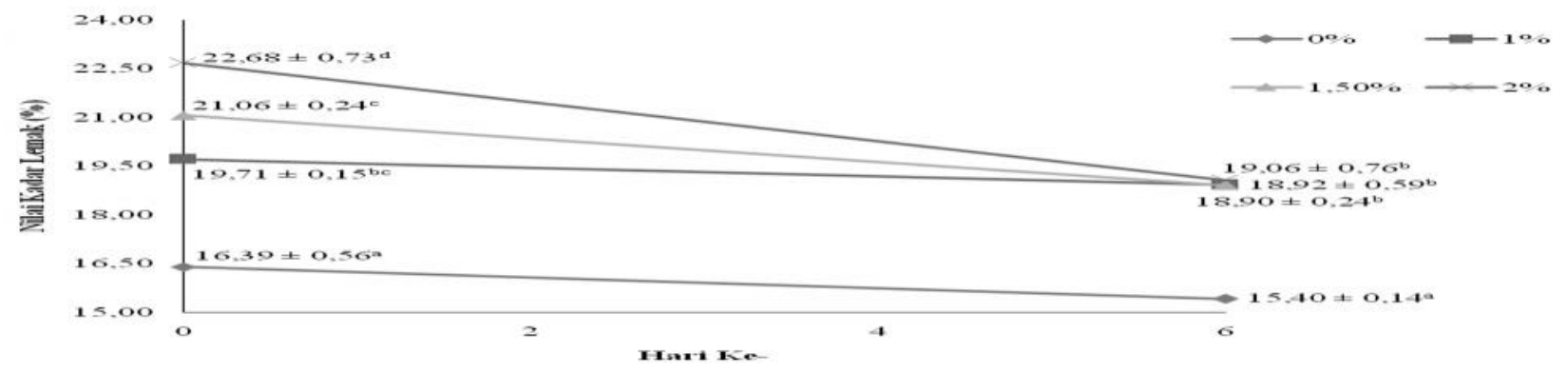

Gambar 4. Hasil Analisa Nilai Kadar Lemak pada sampel.

Keterangan: Data tersebut merupakan hasil rata-rata dari tiga ulangan \pm standar deviasi.

Data yang diikuti dengan tanda huruf kecil yang berbeda pada baris yang sama menunjukkan perbedaan yang nyata ( $P$ $0,05)$.

Perbedaan konsentrasi dan lama penyimpanan mendapatkan hasil yang berbeda nyata terhadap nilai $\mathrm{pH}$. Hal tersebut bisa ditunjukkan selama masa penyimpanan, secara umum nilai $\mathrm{pH}$ pada masing-masing sampel mengalami penurunan sebelum akhirnya mengalami peningkatan. Hal tersebut bisa dilihat pada penambahan konsentrasi $1,5 \%$ dan $2 \%$ selama penyimpanan pada hari ke-2 nilai $\mathrm{pH}$ mengalami penurunan kemudian pada penyimpanan hari ke-4 dan ke-6 nilai $\mathrm{pH}$ mengalami kenaikan. Hasil yang berbeda ditunjukkan pada fillet ikan patin dengan penambahan konsentrasi $1 \%$ mengalami kenaikan pada penyimpanan hari ke-2 lalu mengalami penurunan nilai $\mathrm{pH}$ pada penyimpanan hari ke-4. Secara umum, nilai $\mathrm{pH}$ fillet ikan patin selama penyimpanan dingin dengan penambahan konsentrasi berada dibawah nilai $\mathrm{pH}$ fillet ikan tanpa penambahan konsentrasi (kontrol). Menurut Azzahra et al., (2013) setelah ikan mati, proses glikolisis tetap berlangsung, karena enzim-enzim dalam ikan masih aktif. Oleh karena tidak ada lagi pasokan oksigen, maka tidak lagi terjadi pembentukan glikogen melainkan justru terjadi pembongkaran glikogen menjadi asam laktat ( $\mathrm{pH}$ turun). Selama pendinginan dan pembekuan $\mathrm{pH}$ daging ikan akan berubah. Perubahan ini terjadi dua tahap. Pada tahap awal pendinginan atau pembekuan, $\mathrm{pH}$ daging ikan akan turun kemudian pada tahap selanjutnya $\mathrm{pH}$ akan naik lagi.

\section{Analisa Uji Kadar Lemak}

Berdasarkan nilai kadar lemak yang terdapat pada Gambar 4, nilai kadar lemak yang dihasilkan selama penyimpanan suhu dingin pada semua konsentrasi yaitu konsentrasi $0 \%, 1 \%, 1,5 \%$ dan $2 \%$ mengalami penurunan. Penurunan kadar lemak yang terjadi juga bisa disebabkan oleh penurunan kadar air dan kadar protein selama penyimpanan. Menurut Isa et al. (2015), melaporkan bahwa perubahan kandungan protein selama pertumbuhan sebanding dengan perubahan kadar lemak dalam daging ikan nila. Kandungan protein yang meningkat di dalam tubuh ikan maka kadar lemak akan menurun. Kadar lemak menurun pada saat suhu rendah dan meningkat pada saat suhu tinggi. Hal tersebut juga

() Copyright by Saintek Perikanan (Indonesian Journal of Fisheries Science and Technology), ISSN : 1858-4748 
didukung oleh pendapat Pratama et al., (2014) bahwa kehilangan kadar lemak dan air dapat terjadi karena denaturasi protein pada jaringan dalam tingkatan yang dapat menyebabkan penurunan daya ikat air dan sifat emulsifikasi protein.

Hal tersebut bisa diduga adanya kandungan senyawa fenol yang berperan sebagai antioksidan pada ekstrak Sargassum sp. akan menekan terjadinya reaksi oksidasi sehingga fillet ikan dengan penambahan ekstrak Sargassum sp. mempunyai kadar lemak yang tinggi dibandingkan dengan fillet ikan patin tanpa penambahan ekstrak Sargassum sp. Hal tersebut sesuai pendapat Sanger (2010), yang menyebutkan bahwa senyawa fenol dapat menghambat oksidasi lemak sehingga mencegah kerusakan lemak. Selama penyimpanan kadar lemak cenderung menurun, ini menunjukkan mulai terjadi penguraian lemak karena proses oksidasi atau hidrolisis yang keduanya dapat terjadi secara autolisis maupun kegiatan mikroba.

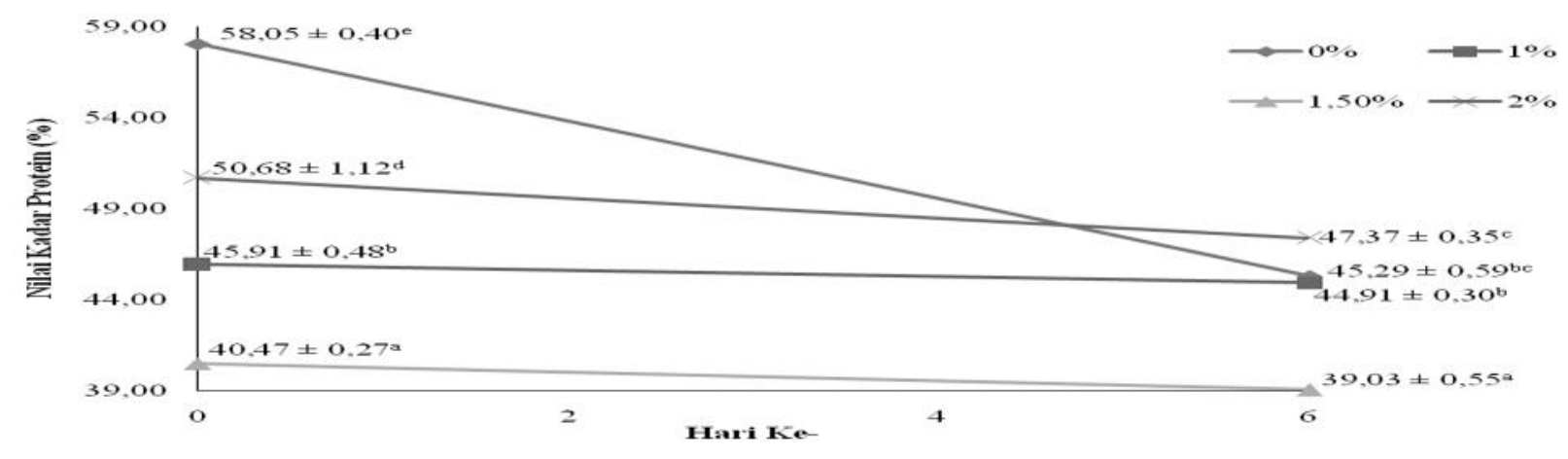

Gambar 5. Hasil Analisa Nilai Kadar Protein pada sampel.

Keterangan: Data tersebut merupakan hasil rata-rata dari tiga ulangan \pm standar deviasi.

Data yang diikuti dengan tanda huruf kecil yang berbeda pada baris yang sama menunjukkan perbedaan yang nyata ( $P$ $0,05)$.

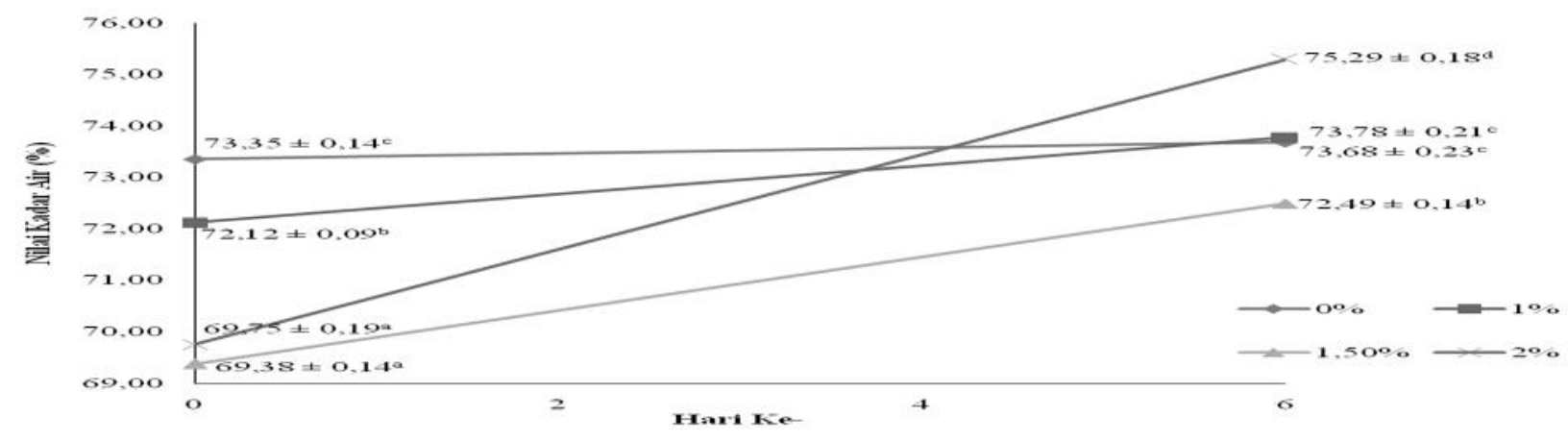

Gambar 6. Hasil Analisa Nilai Kadar Air pada sampel.

Keterangan: Data tersebut merupakan hasil rata-rata dari tiga ulangan \pm standar deviasi.

Data yang diikuti dengan tanda huruf kecil yang berbeda pada baris yang sama menunjukkan perbedaan yang nyata ( $\mathrm{P}$ $0,05)$.

\section{Analisa Uji Kadar Protein}

Berdasarkan data nilai kadar protein pada gambar 5, menunjukkan bahwa nilai kadar protein semakin hari mengalami penurunan. Kadar protein dalam fillet ikan yang di simpan selama beberapa hari kadar proteinnya akan turun karena terjadinya dekomposisi secara perlahan sehingga kekuatan protein dalam mengikat air rendah yang menyebabkan kadar air dalam fillet ikan patin meningkat. Menurut Pratama et al. (2014), tinggi rendahnya nilai protein yang terukur dapat dipengaruhi oleh besarnya kandungan air yang hilang (dehidrasi) dari bahan. Jaelani et al. (2014), menyatakan bahwa aktivitas mikroba selama penyimpanan mengakibatkan terjadinya dekomposisi senyawa kimia daging, khususnya protein yang akan dipecah menjadi senyawa yang lebih sederhana. Hal tersebut didukung oleh pendapat Soeparno (2004), menyatakan bahwa adanya perubahan daya ikat air jaringan otot post-mortem. Perubahan daya ikat air tersebut berkaitan dengan kemampuan protein otot dalam mengikat air, sedangkan kemampuan protein otot dipengaruhi oleh nilai $\mathrm{pH}$ dan jumlah ATP jaringan otot. Daging yang mempunyai $\mathrm{pH}$ tinggi, jauh di atas $\mathrm{pH}$ isoelektrik dari aktomiosin. Maka protein akan mengikat air lebih banyak dan akibatnya daging menjadi kelihatan kering. Pada fase pre rigor daya ikat air daging masih relatif tinggi, akan tetapi secara bertahap menurun seiring dengan nilai $\mathrm{pH}$ dan jumlah ATP jaringan otot.

\footnotetext{
C Copyright by Saintek Perikanan (Indonesian Journal of Fisheries Science and Technology), ISSN : 1858-4748
} 


\section{Analisa Uji Kadar Air}

Berdasarkan data penelitian ini nilai kadar air semakin hari selama penyimpanan mengalami peningkatan. Hal tersebut diduga karena kandungan protein yang semakin menurun sehingga daya ikat air dalam protein tersebut berkurang sehingga kandungan air dalam fillet ikan patin tersebut semakin meningkat. Penurunan daya mengikat air disebabkan oleh makin banyaknya asam laktat yang terakumulasi akibatnya banyak protein miofibril yang rusak, sehingga diikuti dengan kehilangan kemampuan protein daging untuk mengikat air (Wowor et al., 2014). Hal tersebut juga didukung oleh Pratama et al., (2014) bahwa kehilangan kadar lemak dan air dapat terjadi karena denaturasi protein pada jaringan dalam tingkatan yang dapat menyebabkan penurunan daya ikat air dan sifat emulsifikasi protein.

\section{Analisa Uji Organoleptik}

Kenampakan merupakan salah satu parameter terpenting dalam penilaian organoleptik. Hal tersebut dikarenakan kenampakan adalah karakteristik terpenting yang pertama kali diperhatikan oleh konsumen. Penurunan drastis terjadi pada perlakuan kontrol, sedangkan perlakuan dengan penambahan konsentrasi ekstrak Sargassum sp. cenderung stabil serta medapatkan nilai yang lebih tinggi pada akhir lama penyimpanan dibandingkan dengan kontrol. Penurunan yang terjadi selama penyimpanan tersebut disebabkan oleh adanya proses fisika, kimia dan biologi yang terjadi di dalam fillet ikan patin. Waryani et al., (2014), mengatakan bahwa penurunan nilai organoleptik yang drastis menunjukkan ikan telah mengalami pembusukan yang dapat meyebabkan daging ikan menjadi lembut dan lunak. Hal ini disebabkan karena adanya reaksi autolisis yang terjadi sehingga menyebabkan perubahan daging. Fillet ikan patin mudah mengalami kerusakan yang berpengaruh terhadap kenampakannya. Hal tersebut sesuai pendapat Azzahra et al., (2013), bahwa kandungan protein, kadar air yang tinggi serta $\mathrm{pH}$ yang mendekati netral berpengaruh terhadap kerusakan dan penurunan mutu yang berpengaruh terhadap kenampakan fillet ikan patin.

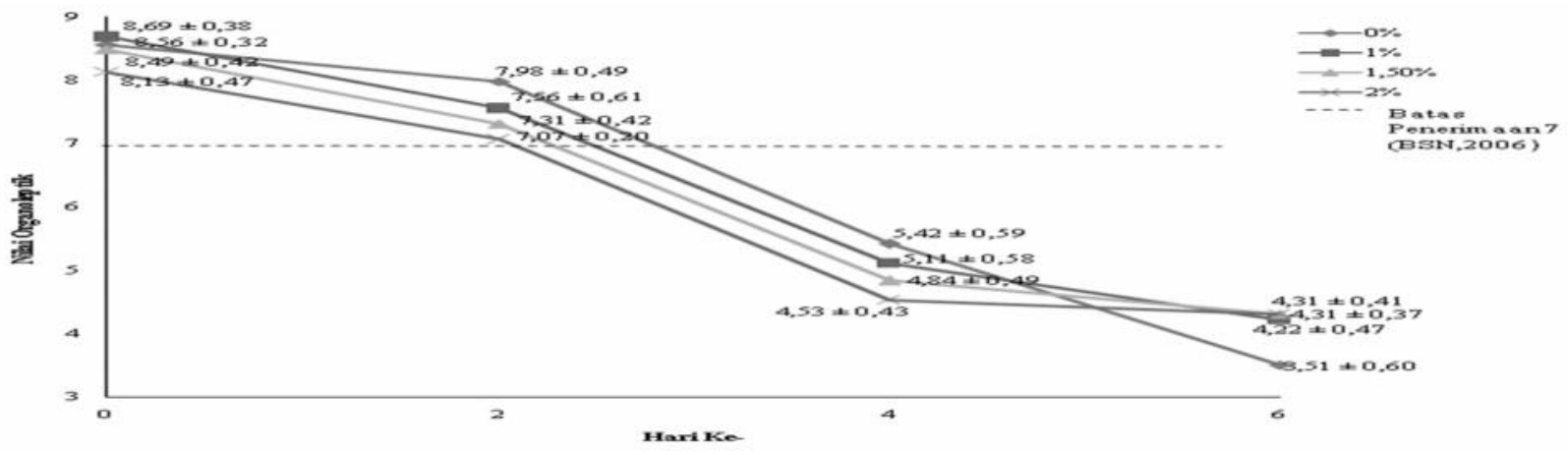

Gambar 7. Hasil Analisa Nilai Organoleptik pada sampel.

Keterangan: Data tersebut merupakan hasil rata-rata dari tiga ulangan \pm standar deviasi.

Berdasarkan pengamatan organoleptik bau fillet ikan patin selama penyimpanan mengalami penurunan drastis terjadi pada hari ke-4. Hal tersebut bisa terjadi karena senyawasenyawa yang terdapat di dalam ikan sudah mulai berubah seperti amoniak uyang menyebabkan bau. Menurut Husni et al., (2014), bau pada fillet ikan disebabkan adanya senyawasenyawa volatil yang berbau seperti amoniak, sehingga mengakibatkan skor organoleptik bau menjadi rendah.

Tekstur merupakan salah satu kriteria yang menentukan tingkat kemunduran mutu produk. Tekstur dapat dirasakan bahan makanan atau produk melalui sentuhan kulit dan penglihatan. Uji organoleptik parameter tekstur pada fillet ikan patin diperoleh rata-rata yang hampir sama pada penyimpanan hari ke-2 yaitu nilai 7. Artinya kondisi masing-masing sampel masih bisa diterima oleh konsumen. Selanjutnya mengalami penurunan sampai pada penyimpanan hari ke-6. Rata-rata nilai organoleptik parameter tekstur pada hari ke-6 mencapai 5 berarti fillet ikan patin tersebut sudah lunak. Hal tesebut sesuai BSN (2006), bahwa parameter tekstur dengan nilai 5 mempunyai spesifikasi kurang elastis, lunak dan kompak.

\section{KESIMPULAN}

Kesimpulan yang diperoleh dari penelitian ini adalah perbedaan konsentrasi ekstrak Sargassum sp. dan lama penyimpanan berpengaruh terhadap oksidasi lemak pada fillet ikan patin (Pangasius sp.) ditunjukkan pada rendahnya nilai PV, TBA dalam fillet ikan patin (Pangasius sp.) dengan

\footnotetext{
() Copyright by Saintek Perikanan (Indonesian Journal of Fisheries Science and Technology), ISSN : 1858-4748
}

penambahan ekstrak Sargassum sp. dibandingkan dengan tanpa penambahan ekstrak Sargassum sp.. Konsentrasi terbaik penggunaan ekstrak Sargassum sp. dalam menghambat oksidasi pada fillet ikan patin (Pangasius sp.) adalah sebesar 1,5\%. Perbedaan konsentrasi ekstrak Sargassum sp. tidak berpengaruh nyata terhadap nilai organoleptik fillet ikan patin, namun lama penyimpanan berpengaruh nyata terhadap nilai organoleptik fillet ikan patin (Pangasius sp.).

\section{UCAPAN TERIMA KASIH}

Penulis mengucapkan terima kasih kepada Laboratorium Teknologi hasil Perikanan FPIK-Universitas Diponegoro dan Laboratorium Teknologi Pangan UGM yang telah membantu kelancaran dalam penelitian ini.

\section{DAFTAR PUSTAKA}

Association of Official Analytical Chemist [AOAC]. 2005. Official Methods of Analysis (18 Edn). Association of Official Analytical Chemist Inc. Mayland. USA.

Apriyantono, A., D. Fardiaz, N.L. Puspitasari, Sedarnawati, dan S. Budiyanto. 1989. Pengaruh Pengolahan Terhadap Nilai Gizi dan Keamanan Pangan. Institut Pertanian Bogor

Azzahra, F. A., R. Utami, dan E. Nurhartadi. 2013. Pengaruh Penambahan Minyak Atsiri Lengkuas Merah (Alpinia purpurata) pada Edible Coating Terhadap Stabilitas 
pH dan Warna Fillet Ikan Patin Selama Penyimpanan Suhu Beku. Jurnal Teknosains Pangan. 2 (4). 2 (4) : 32-38 ISSN: 2302-0733.

Badan Standarisasi Nasioanal. 2006. Petunjuk Pengujian Organoleptik dan atau Sensori. SNI 01-2346-2006.

Dewi, E.N., R. Ibrahim, dan N. Yuaniva. 2011. Daya Simpan Abon Ikan Nila Merah (Oreochromis niloticus Trewavas) yang Diproses dengan Metoda Penggorengan Berbeda. Jurnal Saintek Perikanan, 6 (1): $6-12$.

Djapiala, F. Y., Lita. A.D.Y. Montolalu dan F. Mentang. 2013. Kandungan Total Fenol Dalam Rumput Laut Caulerpa Racemosa yang Berpotensi Sebagai Antioksidan. 1 (2). ISSN: 2337-4284.

Harikedua S. D. 2012. Efek Penambahan Ekstrak Air Jahe (Zingiber officinale Roscoe) dan Penyimpanan Dingin terhadap Mutu Sensori Ikan Tuna (Thunnus albacores). Jurnal Perikanan dan Ilmu Kelautan. 6 (1).

Handayani, T., Sutarno dan A. D. Setyawan. 2004. Analisis Komposisi Nutrisi Rumput Laut Sargassum Crassifolium J. Agardh. Biofarmasi. 2 (2): 45-52. ISSN: 1693-2242.

Hardiana, R., Rudiyansyah., dan Titin, A. Z. 2012. Aktivitas Antioksidan Senyawa Golongan Fenol dari Beberapa Jenis Tumbuhan Famili Malvaceae. Program Studi Kimia, Fakultas MIPA, Universitas Tanjungpura. 1 (1) : 8-13. ISSN: 2303-1077.

Husni, A., Utadi dan A. Hakim. 2014. Penggunaan Ekstrak Rumput Laut Padina sp. untuk Peningkatan Daya Simpan Filet Nila Merah yang Disimpan pada Suhu Dingin. Agritech. 34 (3).

Huss, H.H. 1995. Quality and Quality Changes in Fresh Fish. FAO Fisheries Technical Paper No. 348, Food and Agriculture Organization of The United Nation, Rome.

Jaelani, A., S. Dharmawati dan Wanda. 2014. Berbagai Lama Penyimpanan Daging Ayam Broiler Segar dalam Kemasan Plastik pada Lemari Es (Suhu $4^{\circ} \mathrm{C}$ ) dan Pengaruhnya Terhadap Sifat Fisik dan Organoleptik. Ziraa'ah. 39 (3) : 119-128. ISSN Elektronik 23553545 .

Ketaren, S. 1986. Pengantar Teknologi Minyak dan Lemak Pangan. Edisi Pertama. Penerbit Universitas Indonesia. Jakarta.

Khamidinal, N. Hadipranoto, dan Mudasir. 2007. Pengaruh Antioksidan Terhadap Kerusakan Asam Lemak Tak Jenuh Omega 3 pada Proses Pengolahan Ikan Tongkol. Kaunia. 3 (2).

Khotimah, K., Darius, dan B. B. Sasmito. 2013. Uji Aktivitas Senyawa Aktif Alga Coklat (Sargassum fillipendulla) sebagai Antioksidan pada Minyak Ikan Lemuru (Sardinella longiceps). THPi Student Journal. 1 (1): 10-20.

Munandar. A., Nurjannah, dan M. Nurilmala. 2009. Kemunduran Mutu Ikan Nila (Oreochromis niloticus) pada Penyimpanan Suhu Rendah dengan Perlakuan Cara Kematian dan Penyiangan. Jurnal Teknologi Pengolahan Hasil Perikanan Indonesia. (12) 2.

Muresan, V., S. Muste, E.Racolta, C. A. Semeniuc, S. Man, A. Birou and C.Chircu. 2010. Determination of Peroxide Value in Sunflower Halva using a Spectrophotometric
Method. Bulletin UASVM Agriculture. 67(2). ISSN 1843-5386.

Pendit, P. A. C. D., E. Zubaidah, dan F. H. Sriherfyna. 2016. Karakteristik Fisik-Kimia Dan Aktivitas Antibakteri Ekstrak Daun Belimbing Wuluh (Averrhoa bilimbi L.). Jurnal Pangan dan Agroindustri. 4(1) : 400-409.

Pratama, R. I., I. Rostini, dan E. Liviawaty. 2014. Karakteristik Biskuit dengan Penambahan Tepung Tulang Ikan Jangilus (Istiophorus sp.). Jurnal Akuatika. 5(1). ISSN 0853-2532.

Prawira, J. A. W., Lidya, I. M., dan Vanda, S. K. 2015. Perbandingan Aktivitas Antioksidan Ekstrak Etanol dan Heksana dari Daun Gedi Merah (Abelmoschus manihot). Jurnal MIPA UNSRAT. Vol 4(1): 5-9.

Redha, Abdi. 2010. Flavonoid: Struktur, Sifat Antioksidatif dan Peranannya dalam Sistem Biologis. Jurnal Belian. 9 (2): 196-202.

Rohaeti, E. R. Heryanto, M. Rafi, A. Wahyuningrum, dan L. K. Darusman. 2011. Prediksi Kadar Flavonoid Total Tempuyung (Sonchus Arvensis L.) Menggunakan Kombinasi Spektroskopi IR dengan Regresi Kuadrat Terkecil Parsial. Jurnal Kimia 5 (2) : 101-108. ISSN 1907-9850.

Rafsanjani, M. K. dan W. D. R. Putri. 2015. Karakterisasi Ekstrak Kulit Jeruk Bali Menggunakan Metode Ultrasonic Bath (Kajian Perbedaan Pelarut dan Lama Ekstraksi). Jurnal Pangan Dan Agroindustri. (3) 4:1473-1480.

Septiana, A. T. dan A. Asnani. 2012. Kajian Sifat Fisikokimia Ekstrak Rumput Laut Coklat Sargassum duplicatum menggunakan berbagai Pelarut dan Metode Ekstraksi. Agrointek. 6(1).

Sanger, G. 2010. Oksidasi Lemak Ikan Tongkol (Auxis thazard) Asap yang Direndam dalam Larutan Ekstrak Daun Sirih. Pacific Journal. 2 (5): 870-873. ISSN 1907.9672.

Soeparno . 2004. Ilmu dan Teknologi Daging. Gadjah Mada University Press Yogyakarta.

Suryaningrum, Th. D. 2008. Ikan Patin : Peluang Ekspor, Penanganan Pascapanen dan Diversifikasi Produk Olahannya. Squalen. 3(1).

Suryaningrum, T. D., I. Muljanah, dan E. Tahapari. 2010. Profil Sensori dan Nilai Gizi Beberapa Jenis Ikan Patin dan Hibrid Nasutus. Jurnal Pascapanen dan Bioteknologi Kelautan dan Perikanan. 5(2).

Waryani, S. W., R. Silvia dan F. Hanum. 2014. Pemanfaatan Kitosan Dari Cangkang Bekicot (Achatina fulica) Ebagai Pengawet Ikan Kembung (Rastrelliger sp.) dan Ikan Lele Husni, A., Utadi dan A. Hakim. 2014. Penggunaan Ekstrak Rumput Laut Padina sp. untuk Peningkatan Daya Simpan Filet Nila Merah yang Disimpan pada Suhu Dingin. Agritech. 34 (3).

Winarsi, H. 2007. Antioksidan Alami dan Radikal Bebas Potensi dan Aplikasinya dalam Kesehatan. Kanisius, Yogyakarta.

Wowor, A. K. Y., T. A. Ransaleleh, M. Tamasoleng, dan S. Komansilan. 2014. Lama Penyimpanan Padauhu Dingin Daging Broiler yang Diberi Air Perasan Jeruk Kasturi (Citrus madurensis Lour.) Jurnal Zootek. 34(2) : 148-158. ISSN: 0852-2626.

\footnotetext{
C Copyright by Saintek Perikanan (Indonesian Journal of Fisheries Science and Technology), ISSN : 1858-4748
} 